\title{
Age Changes in Somatotype Components of Rural and Urban Punjabi Brahmin Females
}

\author{
Maninder Kaur \\ Department of Home Science, Kurukshetra University, Kurukshetra, Haryana, India \\ E-mail:Maninderkaur_2@yahoo.co.uk
}

KEYWORDS Endomorphy. Mesomorphy. Ectomorphy. Age Changes. Rural-Urban. Punjabi. Brahmin

\begin{abstract}
The aim of this cross-sectional research was to study the age changes in somatotype components of rural and urban Punjabi Brahmin females, ranging in age from 40 to 70 years. Urban Brahmin females (6.05-4.131.33) are more endomorphic and mesomorphic, but less ectomorphic than their rural counterparts (5.69-3.74-1.76). Both the rural and urban Brahmin females of present study demonstrate dominance of endomorphic component followed by mesomorphic and ectomorphic components throughout the age range under consideration. Mean somatotype ratings of rural and urban Punjabi Brahmin females are concentrated in mesomorphic endomorph sector of the somatochart at all ages and do not exhibit a shift in the component dominance as the age progresses.
\end{abstract}

\section{INTRODUCTION}

A somatotype is a convenient short hand descriptor of over all physique in terms of body shape and composition independent of body size (Carter 1997). It is expressed in a three number rating, representing three components of physique:(1) endomorphy refers to relative fatness (2) mesomorphy refers to musculoskeletal robustness relative to height (3) ectomorphy refers to relative linearity. Sheldon et al. (1969) reported that somatotypes once established remain so throughout life because somatotypes are genetically determined and follows a definite pathway. Zuk (1958), Heath and Carter (1971) and Carter and Parizkova (1978) pointed out that somatotypes of adults followed from adolescence into adult ages continue to change. Carter and Heath (1990) further stated that change and stability of somatotype appear to be functions of nutrition, exercise and health status.

A synthesis of longitudinal and crosssectional studies show that there are significant differences in mean somatotypes between age groups, increasing with length of intervals. Age related variability of the types of body build appeared in association with the developmental heterochronism, which resulted from the uneven growth rate of different body components (Tambovtseva and Zhukova 2005).

Number of studies has summarized the information related to somatotype changes (Singh and Sidhu 1980; Singal and Sidhu 1984; Gaur and Singh 1997; Koleva et al. 2000; Ghosh and Malik
2004; Herrera et al. 2004; Buffa et al. 2005, Bhasin and Jain 2007); but there is no report on this aspect among aged Punjabi Brahmin females residing in rural and urban areas. So, the analysis of present data focuses attention towards the age changes in somatotype components of rural and urban Punjabi Brahmin females.

\section{MATERIAL AND METHOD}

The present study was conducted on a sample of 870 healthy Brahmin females (rural = 450 , urban $=420$ ), ranging in age from 40 to 70 years. Data on various body measurements were collected from year 1999 to 2001. In the first phase, field work was conducted in rural area and in second phase from the urban area. Each subject was contacted individually at her residence. Care was taken to include only normal and healthy individuals, who were not suffering from any chronic disease or physical deformity.

Both the rural and urban subjects belong to one endogamous group that is Brahmins of district RoopNagar (Punjab, India).These two sub-groups of Brahmin population have same broad genetic constitution but are exposed to different environment settings. Earlier Brahmins were a Priest class but now they are engaged in trade, commerce, government and private jobs. Some of the families residing in rural areas were also engaged in agriculture. Some of the most commonly occurring Gotras are Bhardwaj, Bhargava, Gaur, Khausal,Vashisht, Bhanot, Mishra, Joshi, Kalia, Dubey, Pandey. Both the 
rural and urban Brahmin females are believers of Hindu traditions, and worship all Hindu Gods and Goddesses.

The data were arranged in six age groups, each of five years duration except for the first age group, which is of six years duration for both rural and urban punjabi Brahmin females. Age in years had been obtained from the date of birth, which most of the urban females could recall. Whereas in majority of rural females and some aged urban females, age had to be ascertained by association with some important events like age at marriage, age of the first child, any important festival etc. With this cross-questioning, it was possible to ascertain nearly the correct age of the subject.

The anthropometric measurement weight, height, four skinfolds (triceps, subscapular, suprailiac, calf) and two diameters (humerus and femur bicondylar) were taken by using the standard anthropometric techniques given by Weiner and Lourie (1969). Somatotypes were estimated using the Heath and Carter Anthropometric Method (Heath and Carter 1967; Carter 1980). Somatotype Attitudinal Distance (SAD) and Somatotype Attitudinal Mean (SAM) were also calculated. Student's t-test was used to find out magnitude of rural -urban differences at all ages.

\section{RESULTS AND DISCUSSION}

Table 1 presents mean and standard deviation of somatotype components of rural and urban punjabi Brahmin females. The mean somatotype of rural Punjabi Brahmin females at age group 4045 is 6.27-3.91-1.47 and at age group 66-70 is 5.23-
3.11-1.91 (Table 1, Fig.1). Endomorphic component registers a mean value of 6.27 units at age group 40-45, followed by an increase of 0.16 units to reach the maximum value of 6.43 units at age group 46-50, thereafter, a decreasing trend till the age group 56-60 has been observed. Whereafter the mean values for endomorphic components increase by 0.52 units in the next age group and then decrease by 0.19 units to reach at 5.23 units in the age group 66-70. Thus, the endomorphic components in rural females show maximum decline of 1.53 units from age group 46-50 to 56-60.

Mesomorphic component of rural Brahmin female is 3.91units at age group 40-45 and it gains 0.19 units to attain the maximum mean value of 4.10 units at age group 46-50 and finally records a mean value of 3.11 units at $66-70$ years (Fig. 2). A general trend of decrease is witnessed in the mesomorphic rating as the age advances from 46 years onwards, except for the age group 61-65, when the rating increases by 0.14 units. Ectomorphic component of rural Punjabi Brahmin females shows an overall trend of increase with age, with minor fluctuations (Fig. 3). The minimum value for this component has been reported at age group 40-45 (1.47 units) and the maximum at age group 56-60 (2.05 units), resulting in net gain of 0.58 units at this age group.

In urban Punjabi Brahmin females, endomorphic component is reported to be 6.40 units at 40-45 years, followed by a decline of 0.48 units to reach a mean value of 5.92 units at $46-50$ years (Fig. 1). Maximum mean value of 6.46 units has been witnessed at 51-55 years, thereafter a decline is observed till 66-70 years.

Table 1: Mean and standard deviation of somatotype characteristics of rural and urban Punjabi Brahmin females

\begin{tabular}{|c|c|c|c|c|c|c|c|c|}
\hline $\begin{array}{l}\text { Age Group } \\
\text { (in years) }\end{array}$ & $N$ & Endomorphy & t-value & Mesomorphy & t-value & Ectomorphy & t-value & $S A M(S A D / N)$ \\
\hline \multirow[t]{2}{*}{$40-45$} & $\mathrm{R}=75$ & $6.27 \pm 1.61$ & 0.49 & $3.91 \pm 1.13$ & $2.84 * *$ & $1.47 \pm 0.78$ & 0.68 & $1.95 \pm 0.77$ \\
\hline & $\mathrm{U}=70$ & $6.40 \pm 1.52$ & & $4.44 \pm 1.12$ & & $1.39 \pm 0.62$ & & $1.84 \pm 0.71$ \\
\hline \multirow[t]{2}{*}{$46-50$} & $R=75$ & $6.43 \pm 1.51$ & 1.69 & $4.10 \pm 1.48$ & 0.76 & $1.69 \pm 1.17$ & $2.99 * *$ & $2.23 \pm 0.90$ \\
\hline & $\mathrm{U}=70$ & $5.92 \pm 2.06$ & & $4.26 \pm 0.92$ & & $1.24 \pm 0.44$ & & $2.15 \pm 0.78$ \\
\hline \multirow[t]{2}{*}{$51-55$} & $\mathrm{R}=75$ & $5.92 \pm 1.62$ & $2.27 *$ & $3.98 \pm 1.15$ & 1.35 & $1.60 \pm 0.92$ & 0.98 & $2.00 \pm 0.87$ \\
\hline & $\mathrm{U}=70$ & $6.46 \pm 1.18$ & & $4.24 \pm 1.19$ & & $1.46 \pm 0.83$ & & $1.72 \pm 0.70$ \\
\hline \multirow[t]{2}{*}{$56-60$} & $\mathrm{R}=75$ & $4.90 \pm 1.34$ & $7.80 * * *$ & $3.63 \pm 1.20$ & 1.15 & $2.05 \pm 1.51$ & $3.40 * * *$ & $2.10 \pm 1.03$ \\
\hline & $\mathrm{U}=70$ & $6.29 \pm 0.66$ & & $3.86 \pm 1.21$ & & $1.36 \pm 0.76$ & & $1.36 \pm 0.76$ \\
\hline \multirow[t]{2}{*}{$61-65$} & $\mathrm{R}=75$ & $5.42 \pm 1.85$ & 1.18 & $3.76 \pm 0.98$ & $2.46 * *$ & $1.86 \pm 0.98$ & $4.15 * * *$ & $2.14 \pm 0.83$ \\
\hline & $\mathrm{U}=70$ & $5.75 \pm 1.49$ & & $4.19 \pm 1.14$ & & $1.29 \pm 0.63$ & & $1.82 \pm 0.75$ \\
\hline \multirow[t]{2}{*}{$66-70$} & $\mathrm{R}=75$ & $5.23 \pm 1.07$ & 1.43 & $3.11 \pm 1.16$ & $3.47 * * *$ & $1.91 \pm 1.23$ & $3.32 * * *$ & $1.83 \pm 0.77$ \\
\hline & $\mathrm{U}=70$ & $5.50 \pm 1.19$ & & $3.81 \pm 1.27$ & & $1.29 \pm 1.09$ & & $1.80 \pm 0.88$ \\
\hline
\end{tabular}

$\mathrm{p}<0.05^{*} ; \mathrm{p}<0.02^{* * ;} \mathrm{p}<0.01, .001^{* * *} \mathrm{R}=$ rural, $\mathrm{U}=$ urban 


\section{Endomorphic Component}
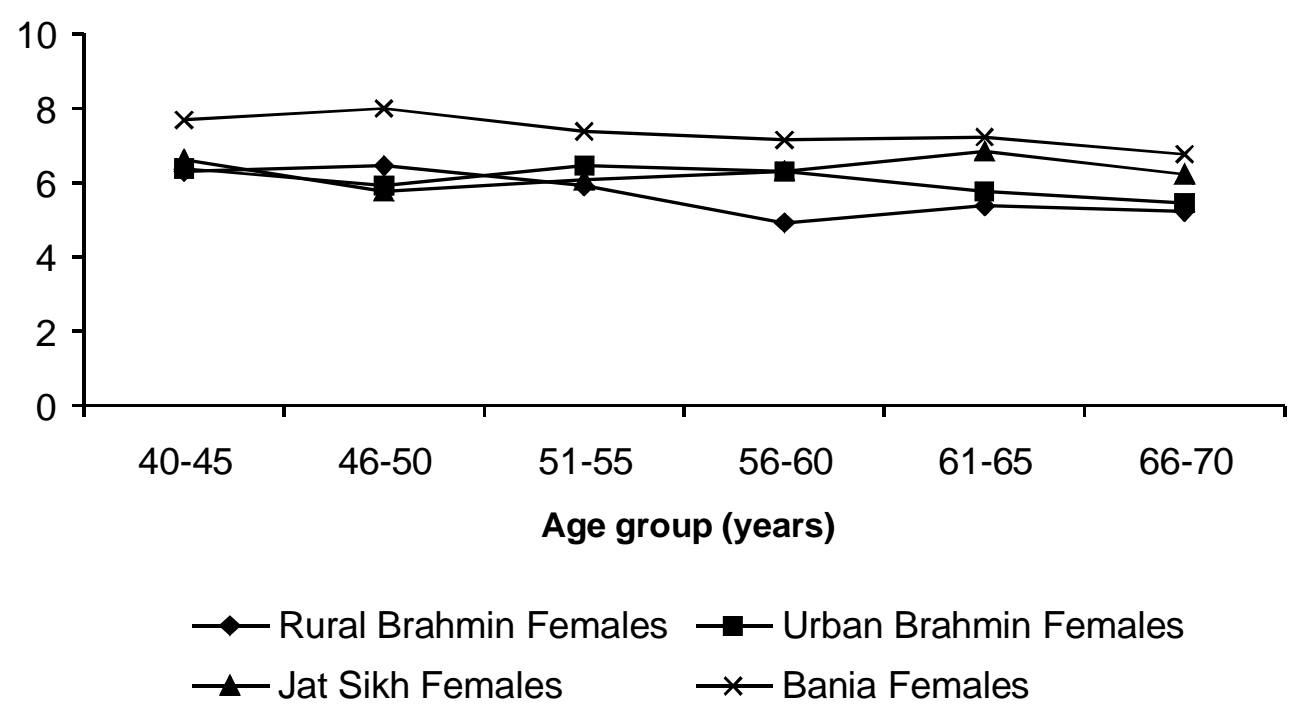

Fig. 1. Comparison of endomorphic component of rural and urban Punjabi Brahmin females with Jat Sikh and Bania females

Mesomorphic component of urban Punjabi Brahmin females show a general trend of decline with the advancing age except for age group 6165 years, where a slight increase is witnessed (Table 1, Fig. 2). Mean value of this component is 4.44 units at age group 40-45, followed by a loss of 0.58 units till age group 56-60 and attains a value of 3.86 units. Thereafter it shows a gain of 0.33 units to reach at 4.19 units at age group 61-65. Maximum decline (0.58 units) in this component is witnessed from $51-55$ years to $56-$ 60 years and over all decline of 0.63 units has been observed with the advancing age. The ectomorphic component in urban punjabi Brahmin females shows an initial decline of 0.15 units to register its maximum value of 1.24 units at age group 46-50.The maximum mean value of 1.46 units is reached at 51-55 years, thereafter a general decline is observed till 66-70 years (Table 1, Fig. 3).

To observe the magnitude of rural and urban differences among three somatotype components, t-value have been presented in (Table 1). At each age level urban Punjabi Brahmin females are more endomorphic than their rural counterparts except for age group 46-50, where rural females exhibit more mean value for this component. However, t-values reveal statistically significant differences at age group 51-55 and 5660 only. Urban females are more mesomorphic than rural females at all ages, but statistically significant results have been obtained at age groups 40-45, 61-65 and 66-70 respectively. Whereas, rural females are more ectomorphic than urban Punjabi Brahmin females at all ages and tvalues reveal statistically significant results at all ages except for age groups 40-45 and 51-55.

Somatotyping is an effective technique for the study of anthropometric variations and body composition in elderly subjects (Buffa et al. 2005). Because of its uniqueness it has been used for studying population variation and/or age and sex variation. Mean somatoplots of females of present study have been compared with samples of Eskimo (Heath 1973), Manus (Heath 1973), Jat Sikh, Bania (Singal and Sidhu 1984) and Canadian females (Bailey et al. 1982) (Fig. 4). The mean Somatotypes of Eskimos, Banias and Manus are widely separated. The Eskimos (6.4-4.4-0.8) and Bania females $(7.4-4.2-1.6)$ are mesoendomorphic, with high endomorphy and mesomorphy. Because of small sample numbers, no age grouping were made for the Eskimos (age 16-75 years) and the Manus (age 18-72 years). Only in the Manus (3.1-4.5-2.5) mesomorphy is greater than endomorphy. Rural and urban Punjabi 


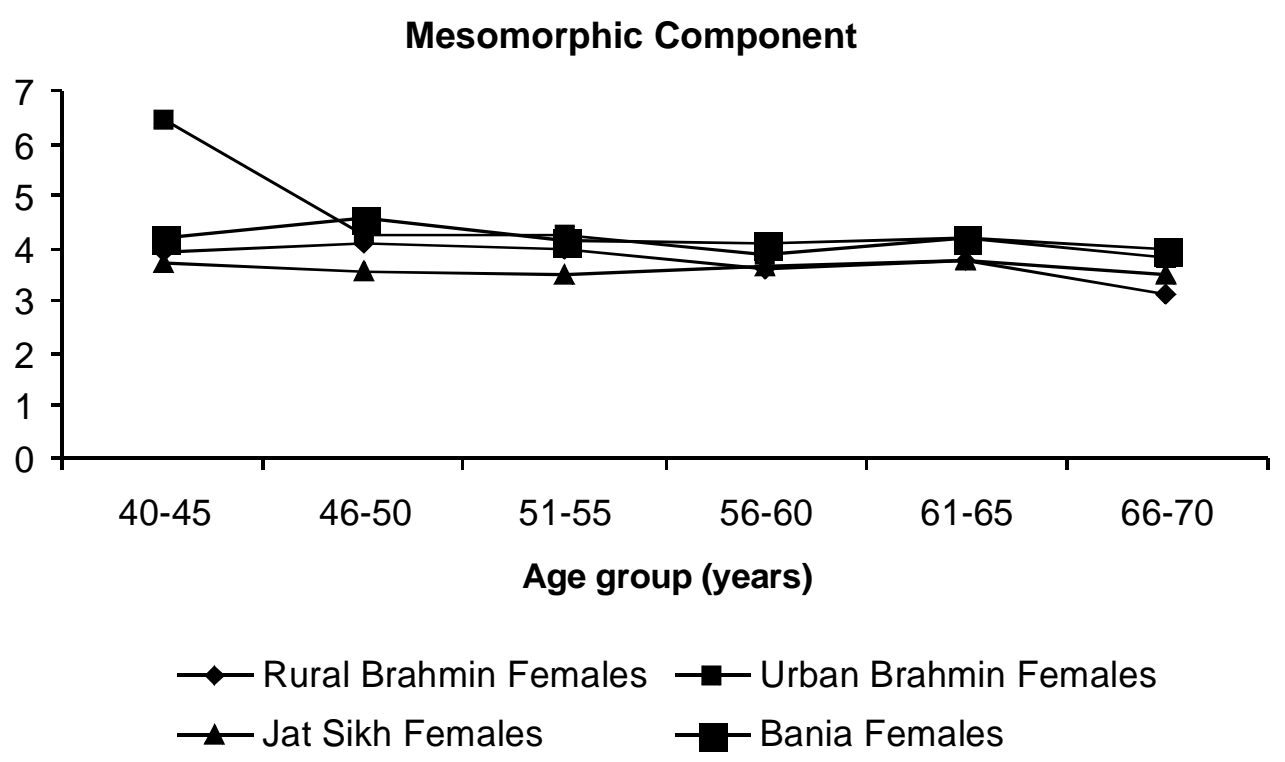

Fig. 2. Comparison of mesomorphic component of rural and urban Punjabi Brahmin females with Jat Sikh and Bania females

\section{Ectomorphic Component}

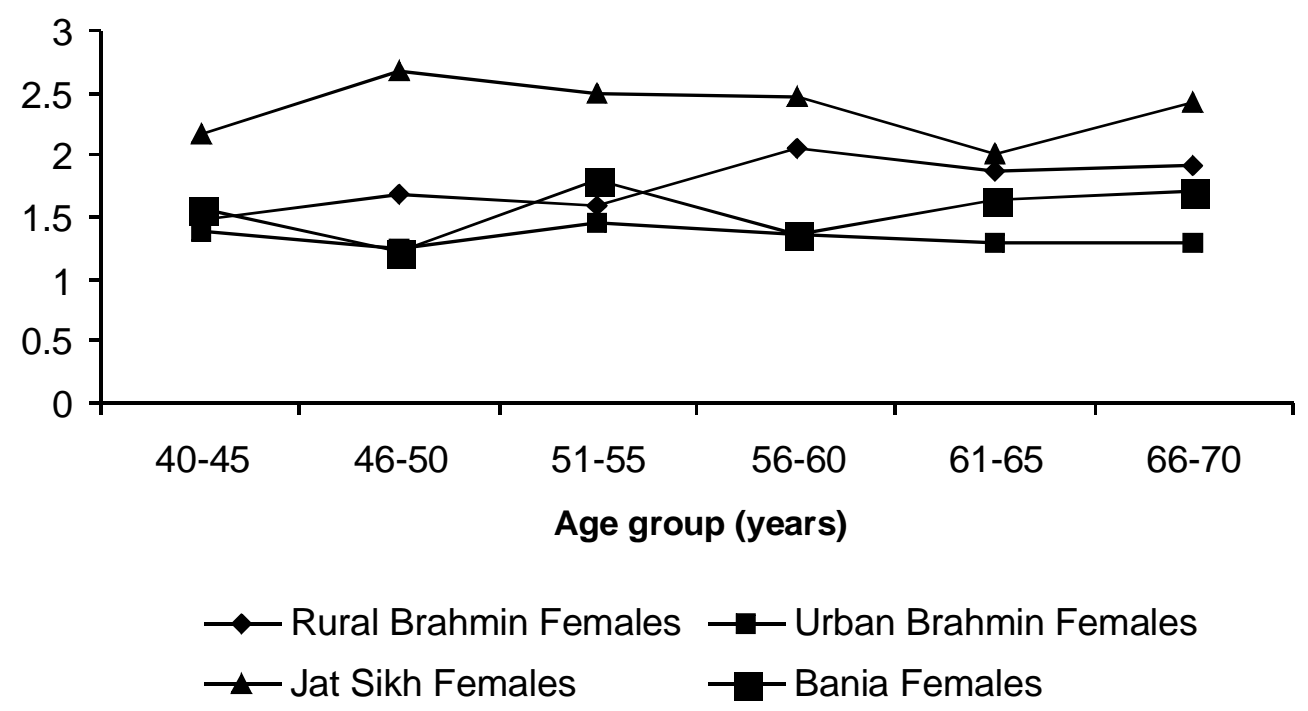

Fig. 3. Comparison of ectomorphic component of rural and urban Punjabi Brahmin females with Jat Sikh and Bania females 
Brahmin females are more ectomorphic than Eskimos but less endomorphic and meso-morphic than them. Punjabi Brahmin females of present study are found to be more endomorphic but less mesomorphic and ectomorphic than Manus.

On comparing the females of present study and Canadian females (5.5-4.6-1.8), urban punjabi Brahmin females are more endomorphic, but less mesomorphic and ectomorphic. While rural Punjabi Brahmin females and Canadian females are relatively close in ectomorphic and endomorphic ratings, but Canadian are more mesomorphic than rural Brahmin females. It is evident from the somatotype distribution that the dominance of endomorphy over mesomorphy is a characteristic of females except for the Manus. Koleva et al. (2000) observed that up to and above 40 years of age over $44 \%$ females were mesomorphic endomorph. Buffa et al. (2005) also reported dominance of endomorphic components among elderly Sardinian females.

Table 2 shows a comparison of rural and urban Punjabi Brahmin females of the present study with
Jat Sikh and Bania females (Singal and Sidhu 1984). Rural Brahmin females are least endomorphic as compared to their urban counterparts, Jat Sikh and Bania females (Fig. 1). Bania and Jat Sikh females are also more endomorphic when compared with urban Brahmin females except at age levels 46-50 and 51-55, where urban Brahmin females exhibit higher rating for this component than Jat Sikh females. However t-values for endomorphic component shows that Bania females exhibit highly significant difference at all ages when compared with rural and urban punjabi Brahmin females (Table 3). Whereas, Jat Sikh and rural Brahmin females reveal statistically significant results from 56-70 years. Jat Sikh and urban Brahmin females show significant differences only from 61-70 years.

Bania females are more mesomorphic than urban Brahmin females except at age levels 40-45 and 51-55.Urban Punjabi Brahmin females show greater rating for this component than Jat Sikh and rural Brahmin female, whereas rural Brahmin females are more mesomorphic than Jat Sikh

Table 2: Age group wise comparison of somatotype components of rural and urban punjabi Brahmin females of the present study with Jat Sikh and Bania females

\begin{tabular}{lcccc}
\hline $\begin{array}{l}\text { Age Group } \\
\text { (in years) }\end{array}$ & $\begin{array}{c}\text { Rural Brahmin } \\
\text { Females }\end{array}$ & $\begin{array}{c}\text { Urban Brahmin } \\
\text { Females }\end{array}$ & $\begin{array}{c}\text { Jat Sikh } \\
\text { Females }\end{array}$ & $\begin{array}{c}\text { Bania } \\
\text { Females }\end{array}$ \\
\hline $40-45$ & $6.27-3.91-1.47$ & $6.40-4.44-1.39$ & $6.63-3.69-2.16$ & $7.68-4.19-1.57$ \\
& $(1.61)(1.13)(0.78)$ & $(1.52)(1.12)(0.62)$ & $(2.13)(1.24)(1.86)$ & $(2.07)(1.45)(1.36)$ \\
$46-50$ & $6.43-4.10-1.69$ & $5.92-4.26-1.24$ & $5.79-3.54-2.68$ & $8.03-4.59-1.23$ \\
& $(1.51)(1.48)(1.17)$ & $(2.06)(0.92)(0.44)$ & $(2.12)(1.11)(1.71)$ & $(1.82)(1.44)(1.22)$ \\
$51-55$ & $5.92-3.98-1.60$ & $6.46-4.24-1.46$ & $6.09-3.50-2.50$ & $7.42-4.14-1.80$ \\
& $(1.62)(1.15)(0.92)$ & $(1.18)(1.19)(0.83)$ & $(1.88)(1.03)(1.67)$ & $(2.12)(1.15)(1.54)$ \\
$56-60$ & $4.90-3.63-2.05$ & $6.29-3.86-1.36$ & $6.30-3.66-2.47$ & $7.19-4.09-1.37$ \\
& $(1.34)(1.20)(1.51)$ & $(0.66)(1.21)(0.76)$ & $(1.76)(1.01)(1.71)$ & $(1.51)(1.00)(0.89)$ \\
$61-65$ & $5.42-3.76-1.86$ & $5.75-4.19-1.29$ & $6.85-3.77-2.00$ & $7.26-4.19-1.65$ \\
& $(1.85)(0.98)(0.98)$ & $(1.49)(1.14)(0.63)$ & $(2.05)(1.22)(1.57)$ & $(1.83)(1.00)(1.47)$ \\
$66-70$ & $5.23-3.11-1.91$ & $5.50-3.81-1.29$ & $6.20-3.52-2.42$ & $6.74-3.98-1.70$ \\
& $(1.07)(1.16)(1.23)$ & $(1.19)(1.27)(1.09)$ & $(1.65)(1.00)(1.38)$ & $(1.91)(1.45)(1.11)$ \\
\hline
\end{tabular}

Table 3: t-values showing age group wise differences in the somatotype components of rural and urban Punjabi Brahmin females of the present study with Jat Sikh and Bania females

\begin{tabular}{|c|c|c|c|c|c|c|c|c|c|c|c|c|}
\hline \multirow[b]{2}{*}{$\begin{array}{l}\text { Age } \\
\text { Group } \\
\text { (in } \\
\text { years) }\end{array}$} & \multicolumn{4}{|c|}{ Endomorphy } & \multicolumn{4}{|c|}{ Mesomorphy } & \multicolumn{4}{|c|}{ Ectomorphy } \\
\hline & $\begin{array}{c}\text { Rural } \\
\text { Brah- } \\
\text { min vs } \\
\text { Jat Sikh }\end{array}$ & $\begin{array}{c}\text { Urban } \\
\text { Brah- } \\
\text { min vs } \\
\text { Jat Sikh }\end{array}$ & $\begin{array}{l}\text { Rural } \\
\text { Brah- } \\
\text { min vs } \\
\text { Bania }\end{array}$ & $\begin{array}{l}\text { Urban } \\
\text { Brah- } \\
\text { min vs } \\
\text { Bania }\end{array}$ & $\begin{array}{l}\text { Rural } \\
\text { Brah- } \\
\text { min vs } \\
\text { Jat Sikh }\end{array}$ & $\begin{array}{l}\text { Urban } \\
\text { Brah- } \\
\text { min vs } \\
\text { Jat Sikh }\end{array}$ & $\begin{array}{l}\text { Rural } \\
\text { Brah- } \\
\text { min vs } \\
\text { Bania }\end{array}$ & $\begin{array}{l}\text { Urban } \\
\text { Brah- } \\
\text { min vs } \\
\text { Bania }\end{array}$ & $\begin{array}{l}\text { Rural } \\
\text { Brah- } \\
\text { min vs } \\
\text { Jat Sikh }\end{array}$ & $\begin{array}{c}\text { Urban } \\
\text { Brah- } \\
\text { min vs } \\
\text { Jat Sikh }\end{array}$ & $\begin{array}{l}\text { Rural } \\
\text { Brah- } \\
\text { min vs } \\
\text { Bania }\end{array}$ & $\begin{array}{l}\text { Urban } \\
\text { Brah- } \\
\text { min vs } \\
\text { Bania }\end{array}$ \\
\hline $40-45$ & 1.10 & & & & & & & & & $3.25 * * *$ & 0.54 & 1.00 \\
\hline & $1.98^{*}$ & & $5.56 * * *$ & $6.10 * * *$ & $2.31 * *$ & $3.91 * * *$ & 1.92 & 1.57 & $3.87 * *$ & $6.75 * * *$ & $2.21 *$ & 0.06 \\
\hline $51-55$ & 0.52 & & $4.64 * * *$ & $3.24 * * *$ & $2.30 * *$ & $3.42 * * *$ & 0.79 & 0.48 & $3.80 * * *$ & $4.43 * * *$ & 0.93 & 1.59 \\
\hline & $4.60 * * *$ & 0.04 & & $4.20 * * *$ & $=0.12$ & 0.84 & 1.90 & 0.93 & & $4.61 * * *$ & $2.37 * *$ & 0.05 \\
\hline $61-65$ & $3.30 * * *$ & $2.88 * * *$ & $4.82 * * *$ & $4.49 * * *$ & 0.04 & 1.57 & $2.10 *$ & 0.00 & 0.53 & $3.17 * * *$ & 0.88 & 1.75 \\
\hline $66-70$ & $3.39 * * *$ & $2.26^{*}$ & $4.93 * * *$ & $3.77 * * *$ & $=1.58$ & 1.03 & $3.04 * *$ & $* 0.55$ & 1.74 & $4.13 * * *$ & $* 0.75$ & 1.60 \\
\hline
\end{tabular}

$\mathrm{p}<0.05^{*} ; \mathrm{p}<0.02 * * ; \mathrm{p}<0.01, .001 * * *$ 


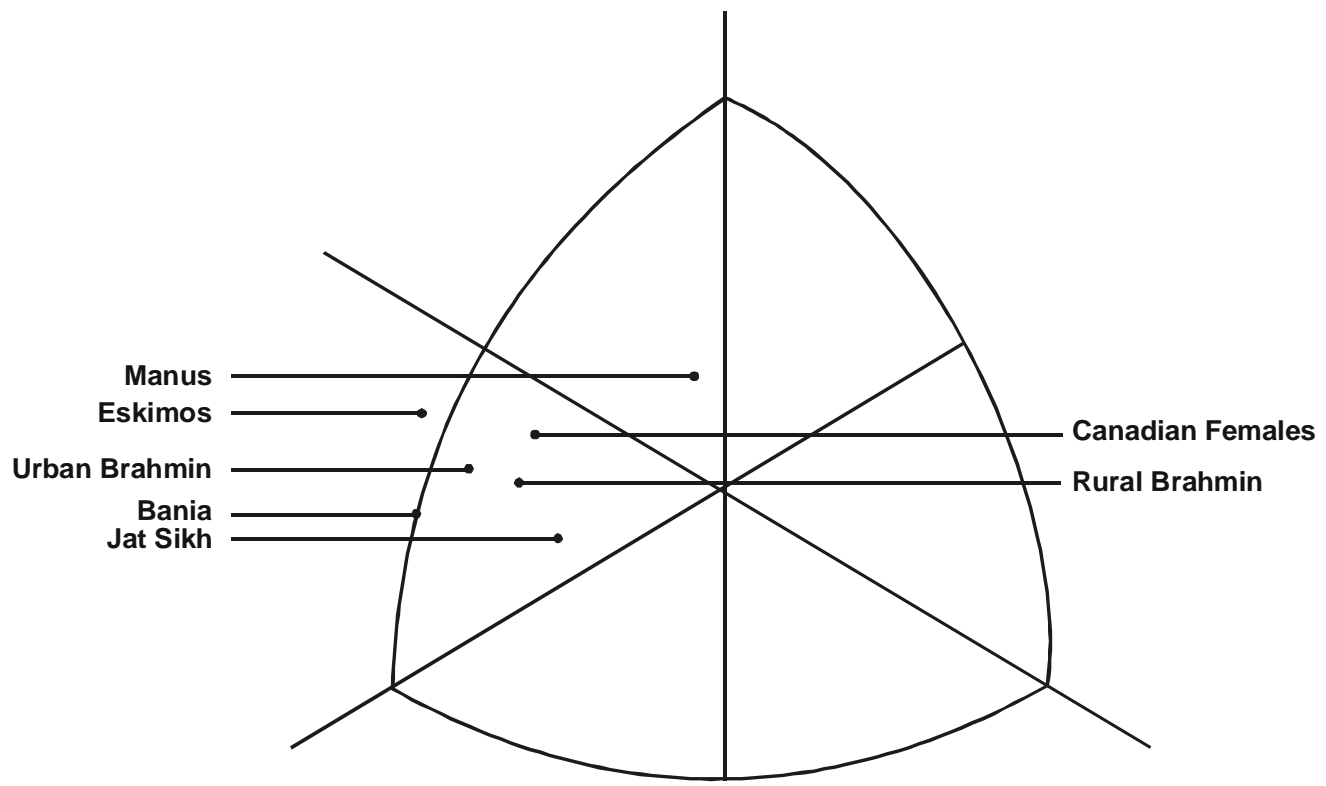

Fig 4. Comparison of mean somatotypes of females ethnic samples

females from 40 to 55 years. Thereafter, Jat Sikh females take a lead in this component with the advancing age. (Fig. 2). t-values reveal that urban Brahmin females show highly significant results only from 40 to 55 years. Rural Brahmin females and Jat Sikh females have highly significant differences only at age levels 46-50 and 5155.Rural and urban Punjabi Brahmin females show non-significant difference with Bania females at all ages except from 61-70 years, where rural Brahmin and Bania females exhibit significant differences.

Jat Sikh females are most ectomorphic and urban Punjabi Brahmin females are the least ectomorphic (Fig. 3). Whereas rural Punjabi Brahmin females show higher rating than Bania females for this component at almost all ages except for $40-45$ years and $51-55$ years, when Bania females register slightly higher rating. For ectomorphic component urban Brahmin and Jat Sikh females present highly significant differences at all ages, whereas rural Brahmin and Jat Sikh reveal statistically significant differences only from ages 40-45years and 51-55 years, as is evident from table-3. Rural Brahmin and Bania females show such differences only at age levels 46-50 years and 56-60 years. Urban Brahmin and Bania females present non-significant results at all ages. Within population variations in somatotype, presumably are due in some measures to genetic factors, dietary pattern, physical activity and other socio-cultural and environmental factors.

Hence, the above results clearly indicate a dominance of the endomorphic and mesomorphic components in the urban Brahmin females, with less development of ectomorphic component than their rural counterparts. Difference in the physique of two sub-groups of Brahmin population may be attributed to different life styles and dietetic characteristics of both the groups. Rural females have more limited opportunities and receive less information on the nutritional requirements, health care services and over all hygine, which adversely affect their quality of life. On the other hand urban Brahmin females are exposed to better education medical services, public health and general awareness.

\section{REFERENCES}

Bailey DA, Carter JEL, Mirwald RL 1982. Somatotype of Canadian men and women. Hum Biol, 54 (4): 813-28.

Bhasin MK, Jain S 2007. Biology of the Tribal Groups of Rajasthan, India: 4. Age changes in somatotype. Anthropologist, 9(4): 257-262.

Buffa R, Succa V, Garau D, Marini E, Floris G 2005. Variations of somatotype in elderly Sardinians. Am J Hum Biol, 17(4): 403-11.

Carter JEL, Parizkova J 1978. Changes in somatotypes 
of European males between 17 and 24 years. American Journal of Physical Anthropology, 48: 251-254.

Carter JEL 1980. The Heath-Carter Somatotype Method, $3^{\text {rd }}$ Edition, San Diego: San Diego State University Syllabus Service.

Carter JEL, Heath BH 1990. Somatotyping: Development and Application. Cambridge / New York: Cambridge University Press.

Carter JEL 1997. Somatotype Analysis-Review and Comments. Ind J Sport Sc P Ed, 9(1 \& 2): 1-10.

Gaur R, Singh SP 1997. Age differences in somatotypes of Garhwali males 17-60 years of age. Am J Hum Biol, 9: 285-290.

Ghosh S, Malik SL 2004. A comparative study of age changes in somatotypes of Brahmin and Rajput boys of Sundarnagar, Himachal Pradesh. Anthropologist, 6(1): 19-23.

Heath BH, Carter JEL 1967. A modified somatotype method. American Journal of Physical Anthropology, 27: 57-74.

Heath BH, Carter JEL 1971. Growth and somatotype patterns of Manus children, Territory of Papua and New Guinea: Application of a modified somatotype method to the study of growth patterns. American Journal of Physical Anthropology, 35: 49-67.

Heath BH 1973. Somatotype patterns and variation within a Melanesian population. Proceedings IXth International Congress of Anthropological and Ethnological Sciences, Chicago.
Herrera H, Rebato E, Hernandez R, Hernandez-Valera Y, Alfonso-Sanchez MA 2004. Relationship between somatotype and blood pressure in a group of institutionalized Venezuelan elders. Gerontology, 50 (4): 223-229.

Koleva M, Nacheva A, Boev M 2000. Somatotype, nutrition and obesity. Rev Environ Health, 15(4): 389-398.

Singal P, Sidhu LS 1984. Age changes and comparison of somatotypes during 20 to 80 years in Jat Sikh and Bania females of Punjab. Anthrop Anz, 42: 281289.

Singh SP, Sidhu LS 1980. Changes in somatotypes during 4 to 20 years in Gaddi Rajput boys. Zeitschrift Fur Morphologie and Anthropologie, 71: 285-293.

Sheldon WH, Lewis NDC, Tenney AM 1969. Psychotic patterns of physical constitution. In: D.V. Siva Sanker (Ed.): Schizophrenia, Current Concepts and Research. Hicksville, New York: PJD Publications, pp. 839-911.

Tambovtseva RV, Zhukova SG 2005. Age related changes of somatotype and body mass component in girls. Morfologiia, 127(1): 48-51.

Weiner JS, Lourie JA 1969. Human Biology: A Guide to Field Methods. IBP Hand book No. 9 Oxford: Blackwell.

Zuk GH 1958. The plasticity of the physique from early adolescence through adulthood. Journal of Genetic Psychology, 92: 205-214. 